\title{
Efficacy of the green lace wing, Chrysoperla zastrowi sillemi (Esben-Peterson) (Neuroptera: Chrysopidae), against sucking pests of tomato: an appraisal under protected conditions
}

\author{
Indu J. Nair, Sudhendu Sharma* (iD and Rabinder Kaur
}

\begin{abstract}
Pest infestations in net-houses are not sometimes different from that under open-field conditions, necessitating usage of pesticides. To examine the hypothesis that bioagents may have more potential under restricted plant growing conditions, the predatory potential of green lace wing, Chrysoperla zastrowi sillemi Esben-Peterson (Neuroptera: Chrysopidae) was evaluated against the sucking pests of tomato under screen-house conditions. The rates of release were fixed as 4, 5, and $6 \mathrm{~s}$ instar grubs plant ${ }^{-1}$ and a total of 3 releases were made at 7 days interval, with first release at appearance of the aphid, Myzus persicae (Sulzer) and whitefly, Bemisia tabaci (Gennadius). The pooled data for the years 2018 and 2019 revealed that, the release rates 4, 5, and 6 grubs plant $^{-1}$ were not statistically different in reducing the population of these pests. The factorial analysis based on the release rate and time of these releases suggested that single release of $C$. zastrowi sillemi at 4 grubs plant ${ }^{-1}$ was effective against sucking pests in tomato grown under screen-house conditions.
\end{abstract}

Keywords: Tomato, Myzus persicae, Bemisia tabaci, Chrysoperla zastrowi sillemi, Protected structures

\section{Background}

India ranks second in the area and production of tomato, Lycopersicon esculentum Mill. Tomato production in the tropics is extremely subjected to abiotic stresses like temperature, airflow, and humidity (Ajwang et al. 2002) and to biotic stresses caused by insects like whitefly, aphids, and thrips, and plant viruses transmitted by these insects (Premachandra et al. 2005). The use of synthetic insecticides is widely adopted for the management of these pests, as they are reported to have a rapid action against them. However, their indiscriminate use has several potential harmful effects, disturbing the ecological balance and creating problems like pest resurgences, resistance to

\footnotetext{
* Correspondence: sudendhu@pau.edu

Department of Entomology, Punjab Agricultural University, Ludhiana 141004,
} India

pesticides and deleterious effects on non-target organisms (Prakash et al. 2008). The overuse of pesticides has led to pesticide laden agricultural produce (Donkor et al. 2016), partially processed (Mwanja et al. 2017).

To fetch higher market price, growing off-season vegetables under screen-house conditions is becoming popupersicae (Sulzer), Aphis gosspii Glover, Bemisia tabac (Genn (Sulzer), Aphis gossypii Glover, Bemisia tabaci Thrips tabaci Lindeman, and Tetranychus urticae Koch may escape through these screens. The microenvironment of the screen-houses provides congenial conditions for the multiplication of these pests. This 
causes net-house cultivators to use chemical pesticides in an inappropriate manner. Plant protection of the agriintensive crops, especially vegetables, through biological control, may provide an alternate ecologically benign way to residue free food production under restricted conditions like net-house cultivation. Augmentative as well as inoculative releases of various biocontrol agents have been successfully established for insect control in a number of field crops (Sharma et al. 2018). In fact, these releases can be much more effective inside greenhouse conditions since it ensures restricted dispersal. Lacewings as one of the most economically important biocontrol agents manage various insect pests, especially sucking pests under different agro-ecosystems. Its wide host range as well as geographical distribution, insecticide resistance, voracious larval feeding ability and amenability to rearing makes it a good bioagent for pest management (Pappas et al. 2011). Chrysoperla zastrowi sillemi Esben-Peterson (Neuroptera: Chrysopidae) is an important natural predator because of its ability to control a multitude of soft bodied insects like coccids, mealybugs, aphids, thrips, psyllids, whiteflies and eggs, and larvae of many lepidopteran pests and mites infesting on various crops. Adult lacewings feed upon nectar, pollen, and sugary plant secretions (Hemalatha et al. 2014). Under Indian context, it is the most economically important chrysopids, which was earlier referred as Chrysoperla carnea Stephens. Hence, a revision in the nomenclature of C. carnea was done and erected C. zastrowi sillemi to include both the population from India as well as Middle East (Henry et al. 2010).

Most studies regarding the evaluation of predatory efficiency of C. zastrowi sillemi has been conducted either in laboratory conditions or in field conditions (Satpathy et al. 2012; Aggarwal and Neetan 2014; Manjunatha et al. 2018). Though some works in greenhouse environment have been conducted (El-Arnaouty et al. 2000; Ahmadzadeh and Hatami 2006), yet very few have been reported for the sucking pests infesting tomato under screen-house conditions. Among various pests, M. persicae and B. tabaci have been reported to cause damage to net-house grown tomatoes in Indian Punjab (Kaur et al. 2010).

Therefore, the objective of this study was to validate and promote the biocontrol technology comprising inundative releases of $C$. zastrowi sillemi for the management of sucking pests viz. M. persicae and Bemisia tabaci in tomato grown under protected structures.

\section{Materials and methods}

\section{Raising of plant material}

An indeterminate variety of tomato "Punjab Sartaj" developed by Department of Olericulture, Punjab Agricultural University, Ludhiana, India, was chosen, which could be successfully grown under net-house conditions. The crop was raised in two screen-houses: one at Entomological Research Farm and the other at New Horticultural Orchard, Punjab Agricultural University, Ludhiana. The experiments were conducted in doubledoor gated screen-house structures made of galvanized iron pipes covered with ultraviolet-stabilized 40 mesh size net. The mesh size thus selected was to provide physical barrier for the insect pests to a large extent, but to assure adequate ventilation of the structures. The screen-house was $31.5 \times 10 \mathrm{~m}$ with an arc-shaped top. The height of the net-house was $3 \mathrm{~m}$ at the center and 2 $\mathrm{m}$ at the side walls. In both the years (2018 and 2019), the crop was transplanted in the last week of January. Seedlings were transplanted on $15 \mathrm{~cm}$ high beds $(3 \mathrm{~m}$ $\times 30 \mathrm{~cm}$ ), keeping a row-to-row and plant-to-plant spacing of $1.20 \mathrm{~m} \times 30 \mathrm{~cm}$, respectively. Plants were trained upright with the help of bamboos and nylon ropes. The crop was raised following all the recommended University Package of Practices for the net-house cultivation, excluding the management of insect pests.

\section{Rearing of C. zastrowi sillemi}

C. zastrowi sillemi grubs, the bioagent was mass reared in the laboratory. About 200 pairs of adults' cultures were maintained at biocontrol unit at Department of Entomology, Punjab Agricultural University, Ludhiana. These adults were then kept in oviposition cages measuring (75 $\mathrm{cm} \times 30 \mathrm{~cm}$ ). The sides of the cage were fitted by nylon wire mesh and the sliding top was fitted with black muslin cloth for harvesting the eggs. The adults were fed daily with swabs containing equal quantity of honey + protein supplement + water + yeast extract dissolved in small quantity of water. The yeast extract was added since it is rich in vitamins (especially B complex) and minerals. The prepared diet was provided daily to the adults kept in a glass vessel. One day old eggs were easily dislodged from the top cover by using a sponge. The eggs collected were used for field release or mass multiplication in the future.

For larval rearing, three day old 120 chrysopid eggs were mixed with $0.75 \mathrm{ml}$ of sterilized Corcyra cephalonica Stainton eggs. On hatching, the larvae start feeding on the Corcyra eggs. On the 3rd day, individual grubs were then transferred to small glass vials. Separation of the grubs was done to prevent cannibalism prevalent in the 2nd instar grubs. The eggs were refilled in the glass vial every 3 days, and it continued till the grubs became pupae. The cocoons were collected $24 \mathrm{~h}$ after their formation and were placed in oviposition cage for emergence and the whole cycle of rearing was repeated.

\section{Treatment protocol}

Second instar chrysopid grubs were released at the rate of 4,5 , and 6 grubs plant $^{-1}$. A total of 3 releases were 
made at 7 days interval, with first release at appearance of the pest. The pre-count data of aphids and whiteflies plant $^{-1}$ were recorded before the release and the population of the sucking pests was recorded 7 days after each release. The population was recorded from 10 randomly selected plants from each replication. The number of aphids and whiteflies were calculated on per plant basis.

\section{Statistical analysis}

The mean population of aphids and whiteflies were subjected to two-way analysis of variance (ANOVA) in randomized block design. Data on population were subjected to square root transformations prior to analysis and are presented as mean \pm standard error (SE).Different treatment means were separated at $P=$ 0.05 (Gomez and Gomez 1984).

\section{Results and discussion}

\section{Efficacy of $C$. zastrowi sillemi against $M$. persicae}

The population of $M$. persicae recorded during evaluation of predatory potential of C. zastrowi sillemi grubs conducted in the year 2018 is shown in Table 1. Observations recorded 7 days after the first release (DAFR) of grubs revealed that all the 3 release treatments were significantly better than untreated control in reducing the aphid population $(P<0.0001)$. At 7 days after the 2 nd release (DASR), and 7 days after 3 rd release (DATR) also, the plants released with Chrysoperla grubs $(4,5$, and 6 grubs plant ${ }^{-1}$ ) were recorded with significantly lower aphid population than the untreated control $(P<$ 0.0001 ). After all the 3 releases, a mean population of 0.52 aphids plant $^{-1}$ was recorded in plants released with 4 grubs, whereas the number of aphids recorded per plant was 0.47 and 0.38 , where the number of grubs per plant released was 5 and 6 , respectively. The 3 release treatments were not statistically different, however they were significantly better $(P<0.0001)$ than untreated control wherein, mean aphid population of 32.45 aphids plant $^{-1}$ was recorded.
Data shown in Table 1 reveals significantly lower population of aphids in all the Chrysoperla release treatments than the control during 2019. At 7 DAFR, 7 DASR, and 7 DATR, a significantly lower population of the aphid was recorded in plants released with chrysopid grubs $\left(4,5\right.$, and 6 grubs plant $\left.{ }^{-1}\right)$ as compared to untreated control $(P<0.0001)$. Mean aphid population $\left(0.66,0.57\right.$, and 0.49 aphids plant $\left.{ }^{-1}\right)$, after the 3 releases in different release rates $\left(4,5\right.$, and 6 grubs plant ${ }^{-1}$, respectively), were not statistically different. Highest mean aphid population (31.67 aphids plant ${ }^{-1}$ ) was recorded in untreated control, which was significantly higher $(P<$ 0.0001) than aphid population recorded on released plants.

\section{Efficiency of C. zastrowi sillemi against B. tabaci}

The data on predatory potential of $C$. zastrowi sillemi evaluated against B. tabaci in tomato plants during 2018 revealed significantly lower population of whiteflies on Chrysoperla released plants than untreated control (Table 2). Plants treated with chrysopid grubs (4, 5, and 6 grubs plant $^{-1}$ ) recorded with a significantly lower population of whiteflies at 7 DAFR, 7 DASR and 7 DATR than in the control $(P<0.0001)$. After all the 3 releases, a mean population of 0.33 whiteflies plant ${ }^{-1}$ was recorded in plants released with 4 grubs plant ${ }^{-1}$, whereas population of 0.27 and 0.31 whiteflies was recorded on plants released with 5 and 6 grubs plant ${ }^{-1}$, respectively. These release treatments were statistically superior $(P<$ $0.0001)$ to untreated control (12.54 whiteflies plant $\left.{ }^{-1}\right)$ in reducing the whitefly population.

In 2019 also, a significantly lower population of whiteflies was recorded on the released plants than the control. Chrysoperla releases $\left(4,5\right.$, and 6 grubs plant $\left.{ }^{-1}\right)$ made at 7 DAFR, 7 DASR and 7 DATR resulted in a significantly lower population of whiteflies $(P<0.0001)$ on tomato plants than that of untreated control. The mean population of whiteflies $\left(0.28,0.29\right.$, and 0.33 plant $\left.^{-1}\right)$ after the 3 releases was not statistically different with the

Table 1 Predatory efficiency of C. zastrowi sillemi against M. persicae under protected cultivation conditions

\begin{tabular}{|c|c|c|c|c|c|c|c|c|c|c|}
\hline \multirow{3}{*}{$\begin{array}{l}\text { Number of } \\
\text { grubs/plant }\end{array}$} & \multicolumn{10}{|c|}{ Mean" number of aphids per plant } \\
\hline & \multicolumn{4}{|l|}{2018} & \multirow[t]{2}{*}{ Mean } & \multicolumn{4}{|l|}{2019} & \multirow[t]{2}{*}{ Mean } \\
\hline & Pre-count & 7 DAFR $^{*}$ & $7 \mathrm{DASR}^{* *}$ & 7DATR ${ }^{* * *}$ & & Pre-count & 7 DAFR* $^{*}$ & $7 \mathrm{DASR}^{* *}$ & 7DATR*** & \\
\hline 4 & $23.87^{\mathrm{a}}$ & $1.27 \pm 0.07^{a}$ & $0.23 \pm 0.03^{a}$ & $0.07 \pm 0.03^{a}$ & $0.52 \pm 0.19^{a}$ & $33.73^{\mathrm{a}}$ & $1.47 \pm 0.09^{\mathrm{a}}$ & $0.43 \pm 0.18^{a}$ & $0.07 \pm 0.07^{a}$ & $0.66 \pm 0.22^{a}$ \\
\hline 5 & $24.60^{\mathrm{a}}$ & $1.20 \pm 0.12^{a}$ & $0.13 \pm 0.03^{a}$ & $0.07 \pm 0.03^{a}$ & $0.47 \pm 0.19^{a}$ & $34.83^{\mathrm{a}}$ & $1.20 \pm 0.15^{a}$ & $0.47 \pm 0.03^{a}$ & $0.03 \pm 0.03^{a}$ & $0.57 \pm 0.18^{a}$ \\
\hline 6 & $25.10^{\mathrm{a}}$ & $1.00 \pm 0.12^{a}$ & $0.10 \pm 0.02^{\mathrm{a}}$ & $0.03 \pm 0.03^{\mathrm{a}}$ & $0.38 \pm 0.16^{\mathrm{a}}$ & $34.67^{\mathrm{a}}$ & $1.00 \pm 0.17^{\mathrm{a}}$ & $0.37 \pm 0.03^{\mathrm{a}}$ & $0.10 \pm 0.02^{\mathrm{a}}$ & $0.49 \pm 0.14^{\mathrm{a}}$ \\
\hline $\begin{array}{l}\text { Untreated } \\
\text { control }\end{array}$ & $29.77^{a}$ & $31.22 \pm 0.20^{b}$ & $32.73 \pm 0.27^{b}$ & $33.40 \pm 0.60^{b}$ & $32.45 \pm 0.38^{b}$ & $36.03^{\mathrm{a}}$ & $30.97 \pm 0.38^{b}$ & $31.43 \pm 0.03^{b}$ & $32.60 \pm 0.06^{b}$ & $31.67 \pm 0.27^{b}$ \\
\hline$P$ value & 0.163 & $<0.0001$ & $<0.0001$ & $<0.0001$ & $<0.0001$ & 0.815 & $<0.0001$ & $<0.0001$ & $<0.0001$ & $<0.0001$ \\
\hline
\end{tabular}

"Mean of three replications

Means \pm standard error followed by the same letter within a column are not significantly different $(P<0.05)$

*7 days after first release

**7 days after second release

***7 days after third release 
Table 2 Predatory efficiency of C. zastrowi sillemi against B. tabaci under protected cultivation conditions

\begin{tabular}{|c|c|c|c|c|c|c|c|c|c|c|}
\hline \multirow{3}{*}{$\begin{array}{l}\text { Number of } \\
\text { grubs/plant }\end{array}$} & \multicolumn{10}{|c|}{ Mean" number of whiteflies per plant } \\
\hline & \multicolumn{4}{|c|}{2018} & \multirow[t]{2}{*}{ Mean } & \multicolumn{4}{|l|}{2019} & \multirow[t]{2}{*}{ Mean } \\
\hline & Pre-count & 7 DAFR $^{*}$ & 7 DASR $^{* *}$ & 7DATR*** & & Pre-count & 7 DAFR $^{*}$ & $7 \mathrm{DASR}^{* *}$ & 7DATR ${ }^{* * *}$ & \\
\hline 4 & $13.60^{\mathrm{a}}$ & $0.63 \pm 0.03^{a}$ & $0.23 \pm 0.03^{a}$ & $0.13 \pm 0.03^{a}$ & $0.33 \pm 0.08^{a}$ & $10.33^{\mathrm{a}}$ & $0.57 \pm 0.20^{\mathrm{a}}$ & $0.20 \pm 0.10^{a}$ & $0.07 \pm 0.03^{a}$ & $0.28 \pm 0.10^{a}$ \\
\hline 5 & $14.13^{\mathrm{a}}$ & $0.50 \pm 0.12^{\mathrm{a}}$ & $0.23 \pm 0.03^{a}$ & $0.07 \pm 0.03^{\mathrm{a}}$ & $0.27 \pm 0.07^{\mathrm{a}}$ & $10.53^{\mathrm{a}}$ & $0.63 \pm 0.09^{\mathrm{a}}$ & $0.20 \pm 0.06^{\mathrm{a}}$ & $0.03 \pm 0.03^{\mathrm{a}}$ & $0.29 \pm 0.09^{a}$ \\
\hline 6 & $12.47^{\mathrm{a}}$ & $0.47 \pm 0.03^{\mathrm{a}}$ & $0.33 \pm 0.07^{\mathrm{a}}$ & $0.13 \pm 0.03^{\mathrm{a}}$ & $0.31 \pm 0.05^{\mathrm{a}}$ & $10.03^{\mathrm{a}}$ & $0.50 \pm 0.15^{a}$ & $0.37 \pm 0.27^{\mathrm{a}}$ & $0.13 \pm 0.03^{\mathrm{a}}$ & $0.33 \pm 0.11^{a}$ \\
\hline $\begin{array}{l}\text { Untreated } \\
\text { control }\end{array}$ & $13.80^{\mathrm{a}}$ & $11.80 \pm 0.31^{b}$ & $12.77 \pm 0.09^{b}$ & $13.07 \pm 0.24^{b}$ & $12.54 \pm 0.22^{\mathrm{b}}$ & $10.10^{\mathrm{a}}$ & $10.10 \pm 1.33^{b}$ & $10.57 \pm 1.50^{\mathrm{b}}$ & $10.60 \pm 0.35^{\mathrm{b}}$ & $10.42 \pm 0.59^{k}$ \\
\hline$P$ value & 0.767 & $<0.0001$ & $<0.0001$ & $<0.0001$ & $<0.0001$ & 0.980 & $<0.0001$ & $<0.0001$ & $<0.0001$ & $<0.0001$ \\
\hline
\end{tabular}

\#Mean of three replications

Means \pm standard error followed by the same letter within a column are not significantly different $(P<0.05)$

*7 days after first release

**7 days after second release

***7 days after third release

releases of grubs at 4, 5, and 6 plant $^{-1}$, respectively. A statistically significant $(P<0.0001)$ higher population of 10.64 whiteflies plant $^{-1}$ was recorded on the plants maintained as untreated control.

The pooled data (2018 and 2019) for the evaluation of C. zastrowi sillemi against M. persicae in tomato under screen-house conditions, shown in Table 3 revealed significantly lower population on the released plant than the control. The plants with different releases $(4,5$, and 6 grubs plant $^{-1}$ ) were recorded with a significantly lower population of $B$. tabaci at 7 DAFR, 7 DASR, and 7 DATR $(P<0.0001)$. The mean population of aphids after the 3 releases showed that the releases of grubs at 4,5 , and 6 plant $^{-1}$ were not statistically different. After 3 releases, a mean population of $0.59,0.52$, and 0.43 aphids plant ${ }^{-1}$ was recorded on plants released with 4,5 , and 6 Chrysoperla grubs plant ${ }^{-1}$, respectively. All the 3 releases were significantly better $(P<0.0001)$ than untreated control (32.06 aphids plant $\left.{ }^{-1}\right)$.

Similarly, pooled data for 2 years (2018 and 2019) for whiteflies revealed significantly lower population on the released plant than the control (Table 3). At 7 DAFR, 7 DASR and 7 DATR, the plants on which Chrysoperla grubs were released $\left(4,5\right.$, and 6 grubs plant $\left.{ }^{-1}\right)$, were recorded with significantly lower whitefly population $(P$ $<0.0001)$ than untreated control. Different grub numbers per plant $(4,5$, and 6$)$ were not statistically different with each other $\left(0.31,0.28\right.$, and 0.32 whiteflies plant ${ }^{-1}$, respectively) in reducing the population of whitefly on screen-house grown tomatoes, but were statistically better $(P<0.0001)$ than untreated control $(11.84$ whiteflies plant $\left.^{-1}\right)$.

In order to protect crops from pests, adverse climatic conditions and to reduce dependency on frequent pesticide use, net/poly cultivation practices are widely adopted in many parts of the world. But these structures have limitations, particularly with small insect pests, which can easily escape through the physical screens provided. These pests multiply rapidly under ambient temperature and relative humidity conditions, thereby resulting in significant crop losses. Under net-/polynet-house conditions, the high predatory potency of chrysopids against sucking pests have earlier been reported against sweet potato whitefly, Bemisia tabaci (Gennadius) (Breene et al. 1992), green peach aphid, Myzus persicae (Sulzer) (El-Arnaouty et al. 2000) and greenhouse whitefly, Trialeurodes vaporariorum West (Ahmadzadeh and Hatami 2006). In greenhouse tomatoes, efficacy of two green lace wings species,

Table 3 Predatory efficiency of C. zastrowi sillemi against M. persicae and B. tabaci under protected cultivation conditions (20182019 pooled)

\begin{tabular}{|c|c|c|c|c|c|c|c|c|c|c|}
\hline \multirow{2}{*}{$\begin{array}{l}\text { Number of } \\
\text { grubs/plant }\end{array}$} & \multicolumn{4}{|c|}{ Mean" number of aphids per plant } & \multirow[t]{2}{*}{ Mean } & \multicolumn{4}{|c|}{ Mean" number of whiteflies per plant } & \multirow[t]{2}{*}{ Mean } \\
\hline & Pre-count & 7 DAFR* $^{*}$ & $7 \mathrm{DASR}^{* *}$ & 7DATR ${ }^{* * *}$ & & Pre-count & 7 DAFR $^{*}$ & $7 \mathrm{DASR}^{* *}$ & 7DATR*** & \\
\hline 4 & $28.80^{\mathrm{a}}$ & $1.36 \pm 0.07^{\mathrm{a}}$ & $0.33 \pm 0.09^{a}$ & $0.07 \pm 0.03^{\mathrm{a}}$ & $0.59 \pm 0.14^{a}$ & $11.97^{\mathrm{a}}$ & $0.60 \pm 0.09^{a}$ & $0.22 \pm 0.05^{a}$ & $0.10 \pm 0.03^{a}$ & $0.31 \pm 0.06^{a}$ \\
\hline 5 & $29.72^{\mathrm{a}}$ & $1.20 \pm 0.09^{a}$ & $0.30 \pm 0.08^{a}$ & $0.05 \pm 0.02^{a}$ & $0.52 \pm 0.13^{\mathrm{a}}$ & $12.33^{\mathrm{a}}$ & $0.57 \pm 0.07^{a}$ & $0.22 \pm 0.03^{\mathrm{a}}$ & $0.05 \pm 0.02^{a}$ & $0.28 \pm 0.06^{\mathrm{a}}$ \\
\hline 6 & $29.88^{\mathrm{a}}$ & $1.00 \pm 0.09^{\mathrm{a}}$ & $0.23 \pm 0.06^{\mathrm{a}}$ & $0.07 \pm 0.02^{\mathrm{a}}$ & $0.43 \pm 0.10^{a}$ & $11.25^{\mathrm{a}}$ & $0.48 \pm 0.07^{\mathrm{a}}$ & $0.35 \pm 0.13^{\mathrm{a}}$ & $0.13 \pm 0.02^{a}$ & $0.32 \pm 0.06^{\mathrm{a}}$ \\
\hline $\begin{array}{l}\text { Untreated } \\
\text { control }\end{array}$ & $32.90^{\mathrm{a}}$ & $31.09 \pm 0.20^{b}$ & $32.08 \pm 0.31^{b}$ & $33.00 \pm 0.32^{b}$ & $32.06 \pm 0.24^{b}$ & $11.95^{\mathrm{a}}$ & $10.95 \pm 0.72^{b}$ & $11.67 \pm 0.8^{b}$ & $11.83 \pm 0.58^{\mathrm{b}}$ & $11.84 \pm 0.40^{b}$ \\
\hline$P$ value & 0.181 & $<0.0001$ & $<0.0001$ & $<0.0001$ & $<0.0001$ & 0.895 & $<0.0001$ & $<0.0001$ & $<0.0001$ & $<0.0001$ \\
\hline
\end{tabular}

\#Mean of three replications

Means \pm standard error followed by the same letter within a column are not significantly different $(P<0.05)$

*7 days after first release

**7 days after second release

***7 days after third release 
C. carnea and Chrysoperla rufilabris (Burmeister) was evaluated against tomato psyllids (Al-Jabr 2000). Both the species were capable of completing their lifecycle on tomato psyllid. C. carnea grub consumed approximately twice as many psyllids as did C. rufilabris, but the development of the latter was faster. The present study also underlines the potential of C. zastrowi sillemi in reducing the population of sucking pests in screen-house grown tomatoes. The second instar grubs at various release rates, i.e., 4,5 , and 6 grubs plant $^{-1}$ significantly reduced the population of aphids and whiteflies on the tomato plants than the control. These release treatments were shown to be equally effective in pest control, even at the lowest release rate tested, i.e., 4 grubs plant ${ }^{-1}$.

One of the major concerns on success of biocontrol agents against crop pests is their performance in the field. These agents are to be used innundatively, i.e., their repeated applications are required. However, there is always an optimal rate at which these bioagents have to be released. The increased release rate may increase the cost of implementing biological control and may not improve the pest control proportionately (Collier and van Steenwyk 2004). There are several studies, wherein increase in release rate of the natural enemies did not affect the pest density significantly (Jung et al. 2004; Alomar et al. 2006). So, under certain pest situations, if farmers have the liberty to decrease the number of releases, it will enhance the adoption of this technology at farm level. The present findings indicate that a single release of Chrysoperla grubs was sufficient for suppressing the population of both $M$. persicae and B. tabaci on tomato plants grown under screen-house conditions.

Further, the timing of biological intervention sometimes has relatively more impact on pest control than the release rate. The release timing affects the host: natural enemy synchrony and decide the successful establishment of a biocontrol agent in the field (Liu and Stansly 2005). We are of the opinion that these grubs were able to the decimate aphid and whitefly population to a negligible level, with the pre-condition that a not very high initial population of these pests was present on tomato plants. The present study is supported by the earlier work of Daane and Yokota (1997) who reported that biological control of vine leafhoppers, Erythroneura variabilis (Beamer) and E. elegantula (Osborn) by Chrysoperla spp. was more affected by the method and timing of application as compared to release rates. Similarly, predatory mite Phytoseiulus persimilis Athias-Henriot managed the two-spotted spider mite, Tetranychus urticae (Koch) effectively, when the predator was released early in the season irrespective of the release rate (Campbell and Lilley 1999). The technology has clear advantages over synthetic chemicals in terms of negligible environmental contamination and adverse impact on non-target organisms. However, concerted research on rational use of these biological entities is required to further explore their functionality and resilience.

\section{Conclusion}

The results conclude that a single release of 2nd instar C. zastrowi sillemi grubs at 4 plant $^{-1}$ may prove effective in reducing the increasing population of $M$. persicae and B. tabaci on screen-house grown tomatoes. Though, a lot depends on the initial incidence of the pests. The results are valuable in generating information on potential management of sucking pests of screen-house grown tomatoes.

\section{Abbreviations}

DAFR: Days after first release; DASR: Days after second release; DATR: Days after third release

\section{Acknowledgements}

The authors are grateful to the Head, Department of Entomology, Punjab Agricultural University, Ludhiana, for providing experimental platform for the successful completion of the work.

\section{Authors' contributions}

IJN carried out the study, analyzed the data, and drafted the manuscript. SS designed the project and was responsible for final interpretation of data. RK maintained the insect culture and edited the manuscript. All authors read and approve the final manuscript.

Funding

Not applicable

Availability of data and materials

All data are available in the manuscript

Ethics approval and consent to participate

Not applicable

Consent for publication

Not applicable

Competing interests

The authors declare that they have no competing interests.

Received: 7 April 2020 Accepted: 2 June 2020

Published online: 16 June 2020

References

Aggarwal N, Neetan (2014) Predatory efficiency of Cheilomenes sexmaculata (Fabricius) and Chrysoperla zastrowi sillemi (Esben-Petersen) on cotton mealy bug, Phenacoccus solenopsis Tinsley under laboratory conditions. Acta Phytopathol Entomol Hung 49:73-81

Ahmadzadeh Z, Hatami B (2006) Evaluation of integrated control of using Chrysoperla carnea (Steph.) and insecticide Confidor in greenhouse conditions. J Crop Prod Process 9:239-251

Ajwang PO, Tantau HJ, Zabeltitz CV (2002) Insect screens for integrated production and protection in greenhouses: A Review of the Physical and Technical Basics. Eur J Hortic Sci 67:45-49

Al-Jabr AM (2000) Integrated pest management of tomato/potato psyllid, Paratrioza cockerelli (Sulc) (Homoptera: Psyllidae) with emphasis on its importance in greenhouse grown tomatoes. Dissertation. Colorado State University

Alomar O, Riudavets J, Castane C (2006) Macrolphus caliginosus in the biological control of Bemisia tabaci on greenhouse melons. Biol Control 36:154-162

Breene RG, Meagher RL Jr, Nordlund DA, Wang YT (1992) Biological control of Bemisia tabaci (Homoptera: Aleyrodidae) in a greenhouse using Chrysoperla rufilabris (Neuroptera: Chrysopidae). BioControl 29:9-14 
Campbell CAM, Lilley R (1999) The effects of timing and rates of release of Phytoseiulus persimilis against two-spotted spider mite Tetranychus urticae on dwarf hops. Biocontrol Sci Tech 9:453-465

Collier T, van Steenwyk R (2004) A critical evaluation of augmentative biological control. Biol Control 31:245-256

Daane KM, Yokota GY (1997) Release strategies affect survival and distribution of green lacewings (Neuroptera: Chrysopidae) in augmentation programs. Environ Entomol 26:455-464

Donkor A, Osei-Fosu P, Dubey B, Kingsford-Adaboh R, Ziwu C, Asante I (2016) Pesticide residues in fruits and vegetables in Ghana: a review. Environ Sci Pollut Res 23:18966-18987

El-Arnaouty SA, Gaber N, Tawfik MFS (2000) Biological control of the green peach aphid Myzus persicae by Chrysoperla carnea (Stephens) (Neuroptera: Chrysopidae) on green pepper in greenhouses in Egypt. Egypt J Biol Pest Control 10:109-116

Gomez KA, Gomez AA (1984) Statistical procedures for agricultural research. Wiley, New York

Hemalatha BN, Venkatesan T, Jalali SK, Reetha B (2014) Distribution and characterization of microbial communities in Chrysoperla zastrowi sillemi, an important predator of sap sucking insect pests. Afr J Microbiol Res 8:14921500

Henry CS, Brooks SJ, Johnson JB, Venkatesan T, Duelli P (2010) The most important lacewing species in Indian agricultural crops, Chrysoperla sillemi (Esben-Petersen), is a subspecies of Chrysoperla zastrowi (Esben-Petersen) (Neuroptera: Chrysopidae). J Nat Hist 44:2543-2555

Jung C, Han S, Lee JH (2004) Release strategies of Amblyseius womersleyi and population dynamics of Amblyseius womersleyi and Tetranychus urticae: II. Test of two release rates on apple. Appl Entomol Zool 39:477-484

Kaur S, Kaur S, Srinivasan R, Cheema DS, Lal T, Ghai TR, Chadha ML (2010) Monitoring of major pests on cucumber, sweet pepper and tomato under net-house conditions in Punjab. Pest Manag Hortic Ecosyst 16:50-57

Liu T, Stansly PA (2005) Timing and release rates for control of Bemisia tabaci (Homoptera: Aleyrodidae) by Nephaspis oculatus (Coleoptera: Coccinellidae) under confined conditions. J Entomol Sci 40:74-79

Manjunatha DK, Sharanabasappa SE, Maruthi MS (2018) Feeding potential of Chrysoperla carnea (Steph.) on different host. J Entomol Zool Stud 6:10281030

Mwanja M, Jacobs C, Mbewe AR, Munyinda SN (2017) Assessment of pesticide residue levels among locally produced fruits and vegetables in Monze District, Zambia. Int J Food Contam 4:11

Pappas ML, Broufas GD, Koveos DS (2011) Chrysopid predators and their role in biological control. J Entomol 8:301-326

Prakash A, Rao J, Nandagopal V (2008) Future of botanical pesticides in rice, wheat, pulses and vegetables pest management. J Biopestic 1:154-169

Premachandra WTSD, Borgemeister C, Maiss E, Knierim D, Poehling HM (2005) Ceratothripoides claratris, a New Vector of a Capsicum chlorosis virus Isolate Infecting Tomato in Thailand. Phytopath 95:659-663

Satpathy S, Kumar A, Shivalingaswamy TM, Rai AB (2012) Effect of prey on predation, growth and biology of green lacewing (Chrysoperla zastrowi sillemi). Indian J Agric Sci 82:55-58

Sharma S, Shera PS, Sangha KS (2018) Impact of bio-intensive integrated pest management practices on insect pests and grain yield in basmati rice. J Biol Control 32:137-141

\section{Publisher's Note}

Springer Nature remains neutral with regard to jurisdictional claims in published maps and institutional affiliations.

\section{Submit your manuscript to a SpringerOpen ${ }^{\circ}$ journal and benefit from:}

- Convenient online submission

- Rigorous peer review

- Open access: articles freely available online

- High visibility within the field

- Retaining the copyright to your article

Submit your next manuscript at $\boldsymbol{\nabla}$ springeropen.com 